\title{
Length-weight relation in the salp Thalia democratica and potential of salps as a source of food
}

\author{
Andrew C. Heron ${ }^{1}$, P. S. McWilliam¹ ${ }^{1}$ G. Dal Pont ${ }^{2}$ \\ ${ }^{1}$ CSIRO Division of Fisheries Research, Marine Laboratories, GPO Box 1538, Hobart, Tasmania 7001, Australia \\ ${ }^{2}$ CSIRO Division of Oceanography, Marine Laboratories, GPO Box 1538, Hobart, Tasmania 7001, Australia
}

\begin{abstract}
Improved methods of analyzing length-weight relations in the fast-growing salp Thalia democratica enable future calculation of productivity from population data and show that carbon density in relation to wet weight for sizes of salps commonly available as food is similar to that of Crustacea. A power relation was developed: Carbon Weight $(\mu \mathrm{gC})=1.62 \times$ Length $(\mathrm{mm})^{1.93},\left(\mathrm{r}^{2}=0.87\right.$, $\mathrm{n}=39$ ). Measurements were taken over a wider range of sizes than before (including $0.4 \mathrm{~mm}$ embryos). No significant difference between solitary and aggregate stages could be detected. Dry weight was $8.04 \%$ of wet weight (SE $=1.01$ ), ash-free dry weight was $46.5 \%$ of dry weight (SE $=1.1$ ), and carbon weight was $38.7 \%$ of ash-free dry weight $(\mathrm{SE}=2.8)$. Carbon was found to be a better reference measurement than either wet or dry weight. The $C: N$ ratio was $3.81: 1$ ( $\mathrm{SE}=0.06$ ). Tissue shrinkage after preservation was significantly different in buffered formalin than in Steedman's solution. Formulae are given for calculating live length from preserved length up to $2 \mathrm{yr}$ after preservation. Previous estimates of wet weight, dry weight and ash in salps were improved by removing internal seawater and salt and driving off most of the 'bound' water; these improvements are also applicable to other gelatinous organisms. Salp weight increases as length squared rather than cubed, because tissue density declines with growth between 3 and $10 \mathrm{~mm}$. Salp tissue density is much closer to that of other marine invertebrates, such as molluscs and crustaceans, than was previously reported in the literature. Contrary to expectations, the ratio of dry and ash-free dry weight to wet weight is high during the most rapid growth period, from 2 to $7 \mathrm{~mm}$. While the average density of $T$. democratica in relation to wet weight is now seen to be comparable to that of molluscs and chaetognaths (not, as previously thought, to that of medusae and siphonophores), the density of $4 \mathrm{~mm}$ individuals reaches that of the arthropods. Coupled with high growth rates, this result makes the salp likely to be a much more important source of food for fish than was previously realized.
\end{abstract}

\section{INTRODUCTION}

Salp populations can grow from 10 to 100 times faster than other dominant zooplankton (Heron \& Benham 1984) and their feeding rates can be much higher than crustaceans for the same carbon biomass (Harbison \& Gilmer 1976). Consequently, their impact on the dynamics of phytoplankton and zooplankton in the ocean can be great. This impact has, however, only recently been recognized in studies of growth and population characteristics (Heron 1972a, b, Deibel 1982a, Heron \& Benham 1984, 1985), aspects of the role of salps in the ocean community (Silver 1975, Wiebe et al. 1980), and the impact of salp feeding on phytoplankton and bacteria (Harbison \& Gilmer 1976, Harbison \& McAllister 1979, Deibel 1982b, Mullin 1983,
Madin \& Cetta 1984, Deibel 1985). There are 47 species of fish now known to feed on salps, many of them as a major part of their diet (Kashinka 1986). Alldredge \& Madin (1982) reviewed the general role of pelagic tunicates in the marine plankton and concluded that their unique adaptations allowed them to make maximum use of the patchy ocean environment.

The impact of salps on the higher levels of the food chain has been limited to the identification of predators (Yount 1958, Heron 1973, Madin 1974, Madin \& Harbison 1977) rather than to measurements of the quantity of salps consumed, because soft-bodied salps are difficult to identify when eaten. Madin et al. (1981) measured the elemental composition of a variety of salps and found them to be potentially valuable to predators since protein was $80 \%$ of the organic matter. 
Direct estimation of secondary production of salps has been little studied because their delicate nature makes them intolerant of laboratory conditions. Calculation of secondary production from time-series of measurements of salp biomass in the ocean has rarely been done as these measurements are difficult to obtain (Le Borgne 1983). However, population growth rate estimates based on indicators of immediate growth rate (Feron \& Benham 1984, 1985), and expressed in terms of length per hour, can be converted to estimates based on weight per hour if length-weight relations are known. Length-weight relations have been estimated for several species of salps (Silver 1971, Harbison \& Gilmer 1976, Deibel 1980, 1982a, Madin et al. 1981) but the only 2 estimates for Thalia democratica (Madin et al. 1981, Deibel 1982a) differ by a factor of about 2 for both the intercept and slope of the regression equation.

The value of salps to predators depends to a large extent on the ratio of seawater in the ingested salp to the salp's dry weight. Most estimates have put salps as similar to Ctenophores in having only $4 \%$ of their wet weight as dry matter (Curl 1961). This is due both to water in the salp's internal cavity and to a much lesser extent to 'bound' water which has been hard to eliminate during drying (Mullin \& Evans 1974).

This paper presents length-weight relations for Thalia democratica, including embryos, which have not been measured before. Shrinkage after preservation affects the application of the relation to preserved samples, and this problem is also addressed.

A comparison was made between the ratio of dry to wet weights for salps and other planktonic animals, since, as a result of this work, wet weight can now be estimated accurately. This ratio is also one indicator of the salp's potential value to fish and other predators.

Our method of estimating length-weight relation in salps, which has proved reliable and accurate, will now make it possible to estimate their productivity correctly, and re-evaluate the role of this fast-growing animal in the dynamics of planktonic food chains.

\section{METHODS}

Collection. Thalia democratica used in lengthweight and carbon and nitrogen determinations were collected from 2 fixed stations of 50 and $100 \mathrm{~m}$ depth off Port Hacking near Sydney (latitude $34^{\circ} \mathrm{S}$ ) on the east coast of Australia during late winter (August) and autumn (April) blooms. To reduce physiological disturbance to the salps during collection and handling, nets of $210 \mu \mathrm{m}$ mesh were deployed for $2 \mathrm{~min}$ within $1 \mathrm{~m}$ of the surface. Without washing down the net, salps in the bucket were immediately transferred to a large, insulated seawater aquarium. Within an hour of capture, the total length of live specimens was measured (to the nearest $0.5 \mathrm{~mm}$ ) as the distance from the oral opening to the posterior ridge of the gut (Measurement B of Foxton 1966). For specimens smaller than $2 \mathrm{~mm}$, length was measured to within $0.05 \mathrm{~mm}$

Carbon was measured in 2 ways: firstly by the sensitive dichromate oxidation method to allow the measurement of very small individuals, and secondly by using a less sensitive $\mathrm{C}: \mathrm{H}: \mathrm{N}$ analyser to allow comparisons with wet, dry and ash weights and nitrogen. A group of 32 samples were analysed by the dichromate oxidation method and a second group of 19 were analysed by the $\mathrm{C}: \mathrm{H}: \mathrm{N}$ analyser.

Carbon analysis versus length. The dichromate oxidation method (Maciolek 1962) for carbon analysis was used on the first group of 32 samples. Each of these samples was made up of from 1 to 300 individuals identical in length and developmental stage (Heron 1972a). The salps in each sample containing more than 1 individual were genetically identical because they were parts of chains of buds produced asexually by the solitary stage. The mean length of individuals in these chain fragments ranged from 0.4 to $12 \mathrm{~mm}$. After the chemical oxidation of the salp tissue, the value found for oxygen consumed was converted to carbon by multiplying by 0.35 , a factor derived by Maciolek (1962) as a ratio of oxygen consumed to $\mathrm{mg}$ carbon in marine organisms.

Carbon and nitrogen versus wet weight, dry weight and ash. A Hewlett Packard 185B C:H:N analyser was used on the second group of 19 samples to determine the relation of carbon to wet weight, dry weight, ashfree dry weight and nitrogen. This cannot be done with the more sensitive dichromate method since the dichromate reagents cannot penetrate dried tissue. Cystine, which has a $C: N$ ratio similar to that of the sample, was used as a reference standard. The 19 separate samples in the second group contained from 1 to 300 individuals per sample. As before, those samples containing more than 1 individual consisted of genetically identical buds from a single chain fragment. These were identical in length and developmental stage. The mean length of these individuals or chain fragments ranged from 3 to $10 \mathrm{~mm}$. The amount of tissue in a $3 \mathrm{~mm}$ salp is at the lower limit for the sensitivity of this method.

All weights were measured on an electrobalance with a resolution of $1, \mathrm{ug}$. The accuracy for weights above $3000 \mu \mathrm{g}$ was $\pm 30 \mu \mathrm{g}$, while the accuracy for weights below $3000 \mu \mathrm{g}$ was $\pm 1 \mu \mathrm{g}$. For comparison, the wet-weight measurements in this study ranged from 524 to $110462 \mu \mathrm{g}$, the dry-weight measurements ranged from 62 to $3517 \mu \mathrm{g}$, and the ash-weight measurements ranged from 23 to $2434 \mu \mathrm{g}$.

Wet weights were determined in precombusted aluminium boats, after removing seawater from the 
salps as described in the section below on interference from salt in seawater.

Dry weights were measured after oven drying at $105^{\circ} \mathrm{C}$ until constant weight was obtained (56 to $72 \mathrm{~h}$ ). The choice of this temperature was determined by the need to remove water and the demonstration that it is a safe temperature to use in relation to lipids (Schindler et al. 1971).

To measure carbon and nitrogen, 7 of the 19 dried samples were first homogenized with a spatula within the boat to allow full penetration of the oxidizing mixture used as a catalyst in the $\mathrm{C}: \mathrm{H}: \mathrm{N}$ analysis. To measure any loss from the homogenization process, the samples were re-dried $\left(100^{\circ} \mathrm{C}\right.$ for $\left.2 \mathrm{~h}\right)$ and re-weighed. They were then combusted in the $\mathrm{C}: \mathrm{H}: \mathrm{N}$ analyzer at a sample chamber temperature of $620^{\circ} \mathrm{C}$ with a carrier gas flow of $120 \mathrm{ml} \mathrm{min}^{-1}$. This low sample temperature combusted for $50 \mathrm{~s}$ was found to be the best routine method for general plankton samples, as carbonates are not volatilized and the life of the instrument is extended while still allowing complete combustion. The $\mathrm{C}$ and $\mathrm{N}$ values obtained after homogenization were adjusted by any small amount lost in the grinding to make them comparable to the initial wet and ash weights.

Ash weights were measured in the remaining 12 of the 19 dried samples by combusting them at $450^{\circ} \mathrm{C}$ for $48 \mathrm{~h}$

The dichromate method is much more sensitive than the $\mathrm{C}: \mathrm{H}: \mathrm{N}$ method for carbon. For example, the carbon weight of the smallest individual salp that could be measured by the dichromate method was $0.47 \mu \mathrm{g} \mathrm{C}$ $(0.4 \mathrm{~mm}$ long), whereas the carbon weight of the smallest individual salp that could be measured by the $\mathrm{C}: \mathrm{H}: \mathrm{N}$ method was $19 \mu \mathrm{g}$ ( $3 \mathrm{~mm}$ long). The carbon weight of smaller individuals (down to $0.34 \mu \mathrm{g}$ ) was obtained by averaging many identical buds from a single chain.

Interference from salt in seawater. A problem with the dichromate oxidation method for marine animals is that salt in internal cavities interferes with the estimation of carbon. Because salps close their valves when removed from seawater, they trap a volume of seawater that is larger than their tissue volume. This seawater was flushed from the internal cavity of the salps with a microsyringe containing isotonic ammonium formate (Parsons et al. 1961). The ammonium formate was later removed by volatilization during the drying process.

To check the contribution of ammonium formate to weight estimations, $40 \mathrm{ml}$ of the isotonic solution and $1 \mathrm{~g}$ of dry crystal of ammonium formate were dried at $105^{\circ} \mathrm{C}$ for $63 \mathrm{~h}$ to simulate the drying procedure, and the residue was weighed. The resulting weight was only $1.1 \%$ of the initial weight. Since this was equiva- lent to the stated impurity level of the salt, it was concluded that all the ammonium formate was evaporated by drying and did not contribute to the weight estimates.

Neither tissue salt nor ammonium chloride was found to interfere with the dichromate oxidation analysis, and there were no indicators of excess salt, such as free chlorine or visible chromium oxychloride. The oxygen equivalent of the amount of chloride present within the body tissue of some large solitary salps was calculated and found to be negligible, as predicted by Maciolek (1962).

Tissue shrinkage in preservative. Shrinkage resulting from preservation was measured in both solitary and aggregate stages of the salps. Total length, endostyle length and wall thickness were measured. Half of a group of 30 live salps of mixed stages ranging from 2.3 to $9.2 \mathrm{~mm}$ in length were preserved in $4 \%$ formalized Steedman's solution made with seawater (Steedman 1976) and transferred after $6 \mathrm{wk}$ to $2 \%$ formalized Steedman's solution (referred to as Treatment 1); the other half were preserved in $5 \%$ buffered formalin and seawater (referred to as Treatment 2). Measurements were made at intervals up to 2 yr from the start of preservation.

\section{RESULTS}

\section{Carbon weight}

Carbon estimated by different methods and in both stages of the life cycle were compared (Table 1). The relation between weight in carbon and length is expressed as a power equation, $\mathrm{W}=a \mathrm{~L}^{b}$, where $\mathrm{W}$ is weight in $\mu \mathrm{g} \mathrm{C}$, L is length in $\mathrm{mm}$ and $a$ and $b$ are the coefficients. Other weight measurements are also given in Table 1 , as well as ranges of lengths and weights from which the means were calculated. The slopes for the various carbon methods ranged from 1.56 to 2.06 with a combined value of 1.93 . The corresponding $\mathrm{r}^{2}$ values ranged from 0.71 to 0.95 . The lowest $\mathrm{r}^{2}$ value was that for the slope value of 1.56 .

Weights estimated by the 2 methods and for both life cycle stages were not significantly different (Table 2). The resulting length-weight regression for carbon (using both methods and both stages) is $W=1.62 \mathrm{~L}^{1.93}$, with $\mathrm{r}^{2}=0.87$ (Fig. 1).

\section{Ash and dry weights}

The mean ash content for aggregate and solitary generations of Thalia democratica was $53.6 \%$ (SE $=$ 1.1) of the dry weight. 
Table 1. Thalia democratica. Parameters of the length-weight relation, $W=a L^{b}$, for aggregate and solitary salps. $\mathrm{n}$ : number of separate length-weight estimates, which are the average of from 3 to 300 identical individuals; $r^{2}$ : coefficient of determination; $a$ and $b$ : regression coefficients for intercept and slope

\begin{tabular}{|c|c|c|c|c|c|c|}
\hline Weight determination & $\mathrm{n}$ & $r^{2}$ & a & $b$ & $\begin{array}{l}\text { Length range } \\
(\mathrm{mm})\end{array}$ & $\begin{array}{c}\text { Weight range } \\
(\mu \mathrm{g})\end{array}$ \\
\hline \multicolumn{7}{|l|}{ Carbon weight } \\
\hline Dichromate method & 32 & 0.86 & 1.39 & 2.06 & $0.45-12.42$ & $0.47-457.50$ \\
\hline $\mathrm{C}: \mathrm{H}: \mathrm{N}$ method & 7 & 0.95 & 1.83 & 1.72 & $0.53-9.80$ & $0.34-88.59$ \\
\hline Combined solitaries & 17 & 0.71 & 2.88 & 1.59 & $1.69-12.42$ & $11.50-457.50$ \\
\hline Combined aggregates & 22 & 0.91 & 1.39 & 2.04 & $0.45-11.98$ & $0.47-409.50$ \\
\hline Combined solitaries and aggregates ${ }^{\circ}$ & 39 & 0.88 & 1.62 & 1.93 & $0.45-12.42$ & $0.47-457.50$ \\
\hline Ash-free dry weight & 12 & 0.93 & 4.17 & 1.96 & $0.75-10.00$ & $3.34-210.00$ \\
\hline Dry weight & 19 & 0.94 & 11.33 & 1.77 & $0.53-10.00$ & $2.24-466.00$ \\
\hline Wet weight & 19 & 0.76 & 317.67 & 1.82 & $0.53-10.00$ & $111.46-39667.00$ \\
\hline
\end{tabular}

Table 2. Thalia democratica. Analysis of covariance of regressions of weight on length determined by 2 methods of analyzing carbon and for both life cycle stages. $n$ : number in each sample

\begin{tabular}{|ccccc|}
\hline & & \multicolumn{2}{c|}{ F-values } \\
\multicolumn{2}{l}{ Comparison of methods } & Regressions & Slopes \\
\hline $\begin{array}{c}\text { Dichro- } \\
\text { mate }\end{array}$ & vs & C:H:N & 0.933 & 1.754 \\
method & $(1 \& 36$ d.f. $)$ & $(1 \& 35$ d.f. $)$ \\
$(\mathrm{n}=32)$ & & $(\mathrm{n}=7)$ & Not sig. & Not sig. \\
$\begin{array}{c}\text { Combined } \\
\text { aggregates }\end{array}$ & vs & solitaries & 0.0004 & 2.188 \\
$(\mathrm{n}=22)$ & & & Not sig. & Not sig. $)$ \\
\hline
\end{tabular}

The relationship of ash-free dry weight to length also showed highly significant correlation and regression coefficients (see Table 1). The regression fitted the power equation $W=4.25 \mathrm{~L}^{1.90}$, with $\mathrm{r}^{2}=0.94$. Carbon was estimated to be $38.7 \%(\mathrm{SE}=2.8)$ of the ash-free dry weight of these Thalia democratica specimens.

Mean dry weight of all individuals used in both $\mathrm{C}: \mathrm{H}: \mathrm{N}$ and ash weight determinations was $8.0 \%$ (SE $=1.01$ ) of the wet weight. The regression of dry weight on length was $W=12.64 \mathrm{~L}^{1.67}$, with $\mathrm{r}^{2}=0.89$

These data also showed a highly significant wet weight to length correlation given by $W=317.67 \mathrm{~L}^{1.81}$, with $r^{2}=0.76$.

\section{$\mathrm{C}: \mathrm{N}$ ratio}

The mean $\mathrm{C}: \mathrm{N}$ ratio of late solitary stages of Thalia democratica was 3.81:1 ( $\mathrm{SE}=0.06$ ). The 5 samples used for this estimation contained a total of 10 individuals of length range 8.3 to $10.0 \mathrm{~mm}$. Unfortunately, only 2 samples of aggregate stages were available for $\mathrm{C}: \mathrm{H}: \mathrm{N}$ analysis and these were both embryos. One sample contained 78 embryos of mean length $0.53 \mathrm{~mm}$. The nitrogen in this sample was below the detectable limit of the analyser so the $C: N$ ratio could not be determined but was probably very high. The other sample contained 10 embryos of mean length $1.5 \mathrm{~mm}$ and had a $C: N$ ratio of 9.5 . A firm relationship for $C: N$ ratio in aggregates or its variation with age therefore could not be determined.

\section{Proportion of ash-free dry weight with length}

The proportion of ash-free dry weight (AFDW) in the salp is highest over the length range from 2 to $7 \mathrm{~mm}$ where it is growing in length the fastest (Fig. 2 and Heron \& Benham 1984). The explanation for the highest rate of increase in length between 2 and $4 \mathrm{~mm}$ is not, therefore, largely due to a rapid uptake of water. As the growth slows between 4 and $10 \mathrm{~mm}$, the proportion of water increases.

The relation was given by:

$\log (\%$ AFDW/Wet wt $)=-2.005+2.868 x-0.538 x^{2}+$ $0.027 \mathrm{x}^{3}$

where $\mathrm{x}=$ length in $\mathrm{mm}$. The relation is significant ( $\mathrm{p}$ $<0.005, \mathrm{~F}_{3,8}=11.23, \mathrm{r}^{2}=0.81$ ).

\section{Tissue shrinkage in preservative}

The shrinkage of Thalia democratica during 2 yr of preservation in Steedman's formalized solutions and in $5 \%$ buffered formalin was measured for both life cycle stages.

Analysis of variance showed a significant difference between the formalin and Steedman's treatments. The interaction of type of preservative and time after pre- 


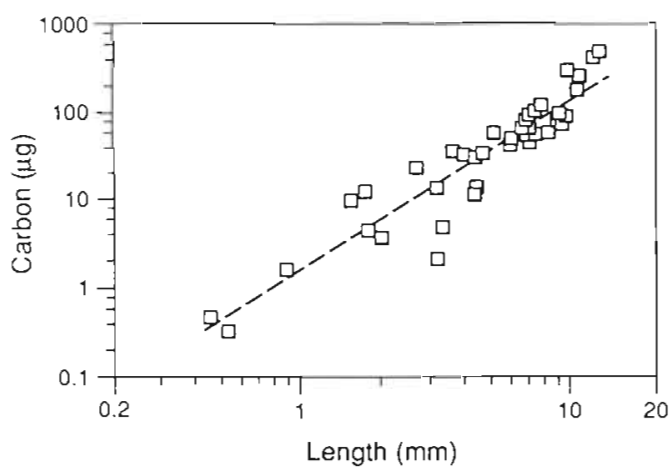

Fig. 1 Thalia democratica. Relation between length and carbon for both life cycle stages and both carbon analysis methods

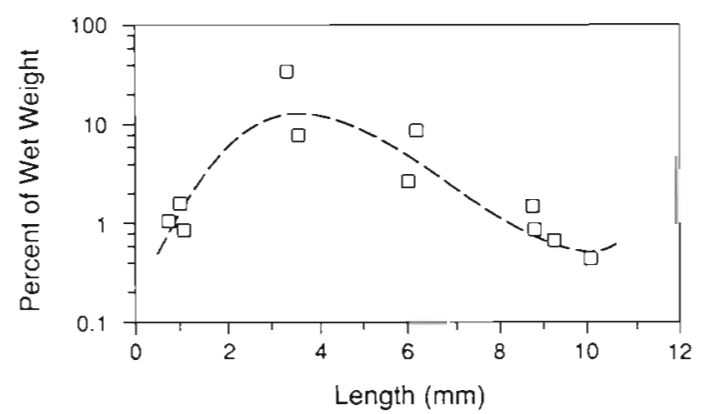

Fig. 2. Thalia democratica. Percentage of ash-free dry weight to wet weight as a function of length

servation was significant $\left(\mathrm{F}_{7.186}=2.749 ; 0.001<p\right.$ $<0.01$ ). During the first 2 to $3 \mathrm{wk}$ after preservation, the formalin-treated tissue shrinks slightly less than that treated with Steedman's, but this difference disappears within a month. However, the appearance of softbodied animals such as salps in formalin is much better, since formalin lacks the softening agents present in Steedman's solution.

Table 3. Thalia democratica and other salps. Comparison of length-weight regressions. The regression formula is carbon weight $=a \times$ length $^{b} . n$ : number of observations; $r^{2}$ : coefficient of determination; $a$ and $b$ : regression coefficients for intercept and slope

\begin{tabular}{|lcccc|}
\hline Source & $a$ & $b$ & $\mathrm{n}$ & $\mathrm{I}^{2}$ \\
\cline { 1 - 4 } Thalia democratica & & & & \\
$\quad$ Heron et al. (this paper) & 1.62 & 1.93 & 39 & 0.87 \\
$\quad$ Deibel (1980, 1982a) & 0.80 & 2.10 & 49 & 0.79 \\
$\quad$ Madin et al. (1981) & 1.13 & 1.78 & 12 & 0.75 \\
$\quad$ Madin et al. (1981) & 1.62 & 1.19 & 12 & 0.45 \\
Other salps & & & & \\
$\quad$ Silver (1971) & 0.79 & 1.82 & - & 0.82 \\
$\quad$ Harbison \& Gilmer (1976) & 1.55 & 1.66 & 8 & 0.67 \\
$\quad$ Harbison \& Gilmer (1976) & 0.61 & 2.15 & 18 & 0.86 \\
$\quad$ Madin et al. (1981) mean & & & & \\
$\quad$ for all with $\mathrm{r}^{2}>0.75$ & 1.43 & 1.78 & 16 & 0.92 \\
\hline
\end{tabular}

The predictive equations for estimating live length from an observed length $x$ days after preservation are:

Formalin: Live length $=$ length $\mathrm{x}_{\mathrm{x}} \times 100 /(94.94-0.932 \mathrm{x}$

$$
-0.045 x^{2} \text { ) }
$$

Steedman's: Live length $=$ length $_{\mathrm{x}} \times 100 /(90.65-$ $0.67 x)$

The regression for formalin is significant $\left(F_{2,97}=22.58\right.$; $\mathrm{p}<0.01 ; \mathrm{r}^{2}=0.318$; residual mean square $\left.=46.84\right)$. The regression for Steedman's is also significant $\left(F_{1,98}\right.$ $=29,0 ; \mathrm{p}<0.01 ; \mathrm{r}^{2}=0.228$; residual mean square $=$ 53.68). The low $r^{2}$ values reflect the inherent variability in length measurements of salps. Therefore the predictive equations will correct the mean lengths but can do nothing about the variability.

\section{DISCUSSION}

\section{Weight determination}

Estimates of carbon in relation to length can be accurate if the sample and the range of body sizes are both large. The slope coefficient of the length-weight

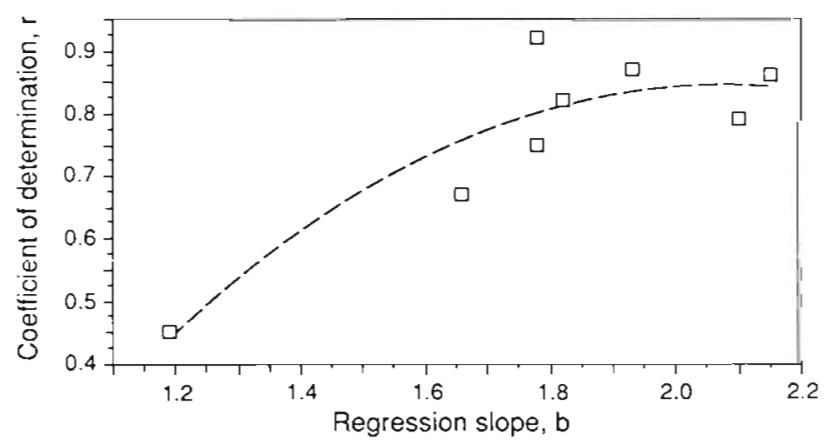

Fig. 3. Relation between slope, $b$, and coefficient of determination, $r^{2}$, for the regression of length on weight in salps

regressions reported in this paper was similar to that estimated by Deibel (1980) (the study with the highest number of observations so far in the literature). This similarity suggests that the numbers and size ranges we both used are sufficient for correct estimation (Table 3).

As the coefficient of determination, $\mathrm{r}^{2}$, increases, the slope of the regression tends towards 2 (Table 3; Fig. 3). This implies that, in salps, the weight is proportional to the length squared, rather than to the length cubed, as is more usual in solid-bodied animals. This trend is also apparent in Table 1 when the exponents for wet weights (1.81), dry weights (1.67), ash-free dry weights (1.90) and carbon weights (1.93) are compared. Weight being proportional to the length squared implies either that the wall thickness is decreasing in proportion to the length with age, or that the density of the salp 
decreases with age. Measurements of wall thickness showed no evidence of a proportional reduction with age. However, density as measured by percentage of ash-free dry weight against length (Fig. 2) decreases markedly over lengths between 2 and $12 \mathrm{~mm}$. All published studies (except the present work) contain only measurements in this range and thus show a slope for the length-weight regression approaching 2 . Even the present study, which has 39 samples, has too few embryos to distinguish 2 possible regression lines in Fig. 1. Based on the density changes in Fig. 2, the first possible regression line ought to extend up to $2 \mathrm{~mm}$. The second possible regression line ought to extend from 2 to $10 \mathrm{~mm}$. Thus the embryos are probably growing with a slope of 3 inside the parent as their density is increasing up to 2 to $3 \mathrm{~mm}$ (Fig. 2). They probably then grow with a slope of 2 outside the parent as their density decreases after 2 to $3 \mathrm{~mm}$. The advantage to salps of decreasing in density after birth, (which results in a rapid increase in volume for a relatively small tissue growth), is likely to be to remove themselves from the size range of predation of the small and numerous planktonic predators and some fish larvae.

Previously published measurements of dry, wet and ash weights are less accurate than measurements of carbon and these estimates differ considerably. We estimated carbon to be $18.0 \%$ of dry weight; Curl (1961), who compared many taxa, estimated carbon in salps as $9.2 \%$ of dry weight; and Madin et al. (1981) estimated carbon as $7.8 \%$ of dry weight (Table 4). Our higher carbon to dry weight ratios are due to our removal of 'bound' water. Since carbon was measured accurately in all studies, any major errors must be in the estimation of dry and wet weights and, therefore, comparisons are best made as ratios of carbon. The current practice of calculating body constituents in terms of wet

Table 4. Comparison of salp constituents from 3 different studies. AFDW ash-free dry weight

\begin{tabular}{|lrrr|}
\hline Ratio & This & Curl Madin et al. \\
& study & $(1961)$ & $(1981)$ \\
\hline Ratios of different weights: & & & \\
$\%$ Dry/wet weight & 8.0 & 4.0 & - \\
$\%$ AFDW/dry weight & 46.5 & 22.9 & 26.6 \\
$\%$ Carbon/dry weight & 18.0 & 9.2 & 7.8 \\
$\%$ Carbon/AFDW weight & 38.7 & 40.0 & 29.4 \\
Ratios of weights to carbon: & & & \\
Carbon & 1 & 1 & 1 \\
AFDW & 2.58 & 2.50 & 3.40 \\
Ash & 2.97 & 8.42 & 9.38 \\
Dry & 5.55 & 10.90 & 12.78 \\
Wet & 69.00 & 272.50 & - \\
Temperature ${ }^{\circ} \mathrm{C}:$ & & & \\
Drying & 105 & 105 & 60 \\
Ashing & 450 & 450 & 400 \\
\hline
\end{tabular}

and dry weight should only be used for assessing the nutritive value of the live animals as food. Thus, if the carbon content of a salp of a given length is normalized to $1 \mathrm{mg}$, the ash-free dry weight per $\mathrm{mg} \mathrm{C}$ of salps becomes $2.58 \mathrm{mg}$ (in the present study), $2.5 \mathrm{mg}$ (in Curl 1961), or $3.4 \mathrm{mg}$ (in Madin et al. 1981) (Table 4).

Estimates of the amount of ash also differ in the 3 studies: we found, for each $\mathrm{mg}$ of carbon, $2.97 \mathrm{mg}$ of ash and only $5.55 \mathrm{mg}$ of dry weight. Curl (1961) found $8.42 \mathrm{mg}$ of ash and $10.9 \mathrm{mg}$ of dry weight per $\mathrm{mg}$ of carbon; Madin et al. (1981) found $9.38 \mathrm{mg}$ of ash and $12.8 \mathrm{mg}$ dry weight. Our lower values can probably be ascribed to our removing the seawater from the internal cavity of the salp before analysis.

The difference between our estimation of wet weight (69.0 $\mathrm{mg}$ per $\mathrm{mg} \mathrm{C}$ ) and Curl's (272.5 $\mathrm{mg}$ per $\mathrm{mg} \mathrm{C}$ ) is probably also due to our removal of seawater from the internal cavity. The ratio of water in these 2 studies (3.9:1) is sufficiently close to that of ash $(2.8: 1)$ to confirm that large amounts of seawater contribute to high values of ash.

Another smaller contribution to our lower dry weights was our use of $105^{\circ} \mathrm{C}$ for drying. Lovegrove (1962) found that plankton dried at $100^{\circ} \mathrm{C}$ stabilized at a weight 5 to $10 \%$ lower than when dried at $50^{\circ} \mathrm{C}$; Curl and others have suggested that this could have been caused by temperatures above 60 to $80^{\circ} \mathrm{C}$ volatilizing lipids. However, this lower weight could have been due, not to the volatilizing of lipids, but to the further removal of water. Achieving constant dry weight at $50^{\circ} \mathrm{C}$ does not mean that all the water has been driven off. A later study compared freeze drying with oven drying at up to $100^{\circ} \mathrm{C}$ and showed no significant difference in the weights obtained by the 2 methods (Schindler et al. 1971). Compared with lipids of general plankton, salp lipids are less likely to be affected by high temperature as microscopic examination shows no evidence of volatile lipid storage globules common at times in Crustacea. These considerations suggest that drying at $100^{\circ} \mathrm{C}$ does not significantly volatilize lipids in salps, although it does remove all the free water.

The ash-free dry weights reported in our study are similar to those of Curl (1961), as are the ashing temperatures used in both studies $\left(450^{\circ} \mathrm{C}\right.$, see Table 4 ). Madin et al. (1981), who ashed at $400^{\circ} \mathrm{C}$, reported higher ash-free dry weights. The differences are probably due to the 'bound' water (Mullin \& Evans 1974, Madin et al. 1981). Madin calculated that $45 \%$ of his ash-free dry weight was 'bound' water (or $41 \%$ if the dry weight of the gut, containing largely non-salp material, is excluded from the total). This would result in $2.01 \mathrm{mg}$ of ash-free dry weight per $\mathrm{mg} C$ as the theoretical minimum value. Since we estimated ashfree dry weight as $2.58 \mathrm{mg}$ per $\mathrm{mg} \mathrm{C}$, our ashing at $450^{\circ} \mathrm{C}$ for $48 \mathrm{~h}$ apparently removed $60 \%$ of Madin's 
estimated 'bound' water. If the extra $40 \%$ of the estimated 'bound' water were subtracted from our results, our estimate of the ash free dry weight as $38.7 \%$ would become $44 \%$, which is about the same as for Crustacea measured by Curl (1961). A temperature higher than $450^{\circ} \mathrm{C}$ would possibly remove the remainder of the 'bound' water. Other workers have used $500^{\circ} \mathrm{C}$ for $5 \mathrm{~h}$ for ashing, even with gelatinous organisms (Hirota 1972). Above this temperature some compounds may volatilize (Paine 1964).

The results of previously published studies can be compared to those done under our conditions if calibration factors are derived for the differences in analytical methods. Thus, dry weights obtained at $60^{\circ} \mathrm{C}$, without prior flushing of the interior cavity with isotonic ammonium formate, can be made comparable to our results at $105^{\circ} \mathrm{C}$ with flushing by dividing by the empirical factor 2.27 derived from Table 4. Similarly, wet weights obtained without flushing can be made comparable to our results by dividing by 4.53. Ash-free dry weight obtained by ashing at $400^{\circ} \mathrm{C}$ for 5 to $8 \mathrm{~h}$ can be made comparable to our results by dividing by 1.5 . Curl (1961) ashed at $450^{\circ} \mathrm{C}$, but for an unspecified time.

\section{Tissue shrinkage}

The results of the shrinkage trials show that salp samples measured 3 mo after preservation are up to $10 \%$ smaller than those measured just after preservation. As such shrinkage could affect the arcuracy of length measurements in population and productivity calculations, the regression formulae should be applied to give consistent estimations of live length.

The techniques used here to improve the analysis of salps, such as high drying and ashing temperatures and the rinsing and flushing of seawater from the animals and their cavities, could be usefully applied to other gelatinous organisms.

\section{Composition of salps and other zooplankton}

The composition of salps does not appear typical of other 'gelatinous' planktonic organisms such as Ctenophores or Medusae when our results are taken into context with those of Madin et al. (1981) and Curl (1961). To compare the composition of salps with that of other zooplankton, we averaged the estimates in Curl (1961) for each taxonomic group, re-expressed them as a percentage of wet weight and then compared them with our results (Table 5).

Our estimates of the general composition of Thalia democratica in Table 5 are higher those of Curl (1961) for tunicates. Two values were calculated for $T$. democratica, the first for the whole size range and the second for the 2 to $7 \mathrm{~mm}$ size range that has the highest density (Fig. 2). Since the density of salps increases over the lengths 2 to $7 \mathrm{~mm}$ (Fig. 2), percentages were also calculated for $4 \mathrm{~mm}$ individuals. These percentages were several times those of the average of all salps sampled. Our value for nitrogen, which is an indicator of protein, is 10 times higher for the mean of all salp stages than that reported for ctenophores and Cnidaria, and is similar to those for molluscs and chaetognaths. The nitrogen value for $4 \mathrm{~mm}$ salps is higher than that for arthropods. Similarly, the other weights for the mean of all salp stages are comparable to molluscs rather than to the previous estimates for tunicates, which placed them with ctenophores and Cnidaria. The $4 \mathrm{~mm}$ stages however, are 2 to 3 times higher still, making them comparable to arthropods.

The value for dry weight of Thalia democratica in the present study is an average of samples representative of the full length range of this species. The lengths most common in the populations of blooms in the East Australian Current and most available to small fish and crustacean predators are in the range of 2 to $5 \mathrm{~mm}$ (Heron 1972a, b), which is also the range with the highest tissue densities. Thus, most of the predation

Table 5. Comparison of general composition of salps with other zooplankton. Weights are expressed as percentages of wet weight

\begin{tabular}{|c|c|c|c|c|}
\hline Group & Dry weight & $\begin{array}{l}\% 0 \\
\text { Ash-free } \\
\text { dry weight }\end{array}$ & $\mathrm{C}$ & $N$ \\
\hline \multicolumn{5}{|l|}{ Curl (1961): } \\
\hline Arthropods & 16.2 & 12.9 & 6.07 & 1.100 \\
\hline Chaetognaths & 10.6 & 8.3 & - & 0.830 \\
\hline Molluscs & 10.4 & 4.2 & 2.84 & 0.400 \\
\hline Ctenophores & 4.9 & 1.3 & 0.31 & 0.032 \\
\hline Cnidaria & 3.2 & 1.3 & 0.44 & 0.030 \\
\hline Tunicates & 4.1 & 1.1 & 0.37 & 0.027 \\
\hline \multicolumn{5}{|l|}{ This study: } \\
\hline Thalia democratica mean & 8.0 & 3.7 & 1.43 & 0.375 \\
\hline Thalia democratica $4 \mathrm{~mm}$ & 20.0 & 14.1 & 5.45 & 1.430 \\
\hline
\end{tabular}


would be on the young stages that are as dense as arthropods.

Because of the now evident high tissue density and nitrogen content of salps, their high growth rates (Heron \& Benham 1984, 1985), the absence of hard parts in the body, and their inability to escape from predators, salps may be a much more significant source of food for fish than was previously realized.

\section{LITERATURE CITED}

Alldredge, A. L., Madin, L. P. (1982). Pelagic tunicates: unique herbivores in the marine plankton. Bioscience $32: 655-663$

Curl, H. (1961). Standing crops of carbon, nitrogen, and phosphorus, and transfer between trophic levels, in continental shelf waters south of New York. Rapp. P.-v. Cons. Réun. int. Explor. Mer 153: 183-189

Deibel, D. R. (1980). Feeding, growth and swarm dynamics of neritic tunicates from the Georgia Bight. Ph. D. thesis, Univ. of Georgia, Athens

Deibel, D. R. (1982a). Laboratory-determined mortality, fecundity and growth rates of Thalia democratica Forskal and Dolioletta gegenbauri Uljanin (Tunicata, Thaliacia). J. Plankton Res. 4: 143-153

Deibel, D. R. (1982b). Laboratory-measured grazing and ingestion rates of Thalia democratica Forskal and Dolioletta gegenbauri Uljanin (Tunicata, Thaliacia). J. Plankton Res. 4: 189-201

Deibel, D. R. (1985). Clearance rates of the salp Thalia democratica fed naturally occurring particles. Mar. Biol. 86: 47-54

Foxton, P. (1966). The distribution and life history of Salpa thompsoni Foxton with observations on a related species, Salpa gerlachei Foxton. Discovery Rep. 34: 1-116

Harbison, G. R., Gilmer, R. W. (1976). The feeding rates of the pelagic tunicate Pegea confederata and two other salps. Limnol. Oceanogr. 21: 517-528

Harbison, G. R., McAlister, V L. (1979). The filter-feeding rates and particle retention efficiencies of three species of Cyclosalpa (Tunicata, Thaliacia). Limnol. Oceanogr. 24: 875-892

Heron, A. C. (1972a). Population ecology of a colonizing species: the pelagic tunicate Thalia democratica. I. Individual growth rate and generation time. Oecologia (Berl.) 10: $269-293$

Heron, A. C. (1972b). Population ecology of a colonizing species: the pelagic tunicate Thalia democratica. II. Population growth rate. Oecologia (Berl.) 10: 294-312

Heron, A. C. (1973). A specialized predator-prey relationship between the copepod Sapphirina angusta and the pelagic tunicate Thalia democratica. J mar biol. Ass. U.K. 53: $429-435$

Heron, A. C., Benham, E. E. (1984). Individual growth rates of salps in three populations. J. Plankton Res. 6: 811-828

Heron, A. C., Benham, E. E. (1985). Life history parameters as indicators of growth rate in three salp populations. $J$. Plankton Res. 7: 365-379
Hirota, J. (1972). Laboratory culture and metabolism of the planktonic ctenophore, Pleurobrachia bachei A. Agassiz. In: Takenouti, A. Y (ed.) Biological oceanography of the northern Pacific Ocean, p. 465-484

Kashinka, A. A. (1986). Feeding of fishes on salps (Tunicata, Thaliacia). J. Icthyol. 26: 57-64

Le Borgne, R. (1983). Note sur les proliférations de thaliacés dans le golfe de Guinée. Océanogr trop. 18: 49-54

Lovegrove, T. (1962). The effects of various factors on dry weight values. Rapp. P.-v. Réun. Cons, int. Explor. Mer 153: 86-91

Maciolek, J. A. (1962). Limnological organic analyses by quantitative dichromate oxidation. U.S. Fish and Wildlife Service, Sport Fisheries and Wildlife. Res. Rep. 60

Madin, L. P. (1974). Field observations on the feeding behaviour of salps (Tunicata: Thaliacea). Mar. Biol. 25: 143-147

Madin, L. P., Cetta, C. M. (1984). The use of gut fluorescence to estimate grazing by oceanic salps. J. Plankton Res. 6: $475-492$

Madin, L. P., Cetta, C. M., McAlister, V L. (1981). Elemental and biochemical composition of salps (Tunicata: Thaliacea). Mar. Biol. 63: 217-226

Mullin. M. M. (1983). In situ measurement of filtering rates of the salp, Thalia democratica, on phytoplankton and bacteria. J. Plankton Res. 5: 279-289

Mullin, M. M., Evans, P. M. (1974). The use of a deep tank in plankton ecology. 2. Efficiency of a planktonic food chain. Limnol. Oceanogr. 19: 902-911

Paine, R. (1964). Ash and caloric determinations of sponge and opisthobranch tissues. Ecology (Durham, N.C.) 45: 384-387

Parsons, T. R., Stephens, K., Strickland, J. D. H. (1961). On the chemical composition of eleven species of marine phytoplankters. J. Fish. Res. Bd Can. 18: 1001-1016

Schindler, D. W., Clark, A. S., Gray, J. R. (1971). Seasonal calorific values of freshwater zooplankton, as determined with a Phillipson Bomb Calorimeter modified for small samples. J. Fish. Res. Bd Can. 28: 559-564

Silver, M. W. (1971). The habitat of Salpa fusiformis (Chordata: Tunicata) in the California Current as defined by stomach content studies and the effect of salp swarms on food supply of the plankton community. Ph. D. thesis, Univ. of California, San Diego

Silver, M. W. (1975). The habitat of Salpa fusiformis in the California Current as defined by indicator assemblages. Limnol. Oceanogr. 20: 230-237

Steedman, H. F. (1976). General and applied data on formaldehyde fixation and preservation of marine zooplankton. In: H. F. Steedman (ed.) UNESCO Monographs on Oceanographic Methodology 4, p. 103-154

Wiebe, P. H., Madin, L. P., Haury, L. R., Harbison, G. R Philbin, L. M. (1980). Diel vertical migration by Salpa aspera and its potential for large-scale particulate organic matter transport to the deep-sea. Mar. Biol. 53: 249-255

Yount, J. L. (1958). Distribution and ecological aspects of central Pacific Salpidae (Tunicata). Pacif. Sci. 12: 111-130 